\title{
Study on Characteristics of Geopolymer Concrete with E-Waste
}

\author{
M. Lenin Sundar ${ }^{1}$, Sherine Raj ${ }^{2}$ \\ I(Professor, Department of Civil Engineering, Sri Krishna College of Technology, Coimbatore, India) \\ ${ }_{2}^{2}$ (Graduate Student, Department of Civil Engineering, Sri Krishna College of Technology, Coimbatore, India)
}

\begin{abstract}
The usage of industrial by-products in construction industry can be reduced the pollution effects on environment. Geopolymer concrete is a concrete in which Portland cement is fully replaced by fly ash and GGBS (Ground granulated blast furnace slag). The present study covers the use of E-Waste as partial replacement of fine aggregate in Geopolymer concrete. Sand is replaced with E-Waste at 10, 20 and 30 percentage.Alkaline liquids used in this study are the solutions of sodium hydroxide ( $\mathrm{NaOH}$ ) and sodium silicate $\left(\mathrm{Na}_{2} \mathrm{SiO}_{3}\right)$. Molarity of sodium hydroxide (12M) is considered. Fly ash and GGBS were used in the combination of 90 and 10 percent respectively. This study conducted to know the compressive and tensile strengths of Geopolymer concrete with E-waste and to compare the same with Geopolymer concrete. It has been revealed that 20 percentage replacement with E-Waste attained higher strength than the normal Geopolymer concrete of M40 grade.
\end{abstract}

Keywords: Geopolymer concrete, Fly ash, GGBS, alkaline solution, E-waste, Mechanical Properties

\section{Introduction}

Concrete is the most widely used construction material in the world. Ordinary Portland Cement (OPC) has been traditionally used as the binding material for concrete. The manufacturing of OPC requires the burning of large quantities of fossil fuels and decomposition of limestone which results in significant emissions of carbon-dioxide $\left(\mathrm{CO}_{2}\right)$ to the atmosphere. This $\mathrm{CO}_{2}$ emission is the main cause for global warming [1]. In order to reduce this, Geopolymer technology was introduced. New electrical and electronic products have become an integral part of our daily lives providing us with more comfort, security, easy and faster acquisition. Due to technological growth, there is a high rate of obsolescence in the electronic equipments which leads to one of the fastest growing waste streams in the world. This waste stream consists of end of life electrical and electronic equipment products. The European Union (EU) defines this new waste stream as Waste Electrical and Electronic Equipment (WEEE) [2]. Since there is no definition of the WEEE in the environmental regulations in India, it is simply called E-waste [3]. E-waste encompasses ever growing range of obsolete electronic devices, such as computers, servers, main frames, monitors, TVs and display devices, cellular phones, calculators, audio and video devices, printers, scanners, copiers, refrigerators, air conditioners, washing machines, microwave ovens, electronic chips, processors, mother boards, printed circuit boards (PCBs), industrial electronics such as sensors, alarms etc.., Electronic and electrical equipment's are made up of several components, many of which contains toxic substance, like lead, chromium, mercury, beryllium, cadmium, acids and plastics etc. [3]

The processing of electronic waste in developing countries causes serious health and pollution problems due to electronic equipment contains serious contaminants such as lead, Cadmium, Beryllium, Arsenic, Mercury, Nickel, Silver, Zinc, Copper, Chrome, Cobalt etc. Pollutants or toxins in e-waste are typically concentrated in circuit boards, batteries, plastics and LCDs (liquid crystal displays). This paper deals with the nonhazardous and inert components of E-waste generated out of Obsolete Computers, TV Cabins, Refrigerator, Mobile phones and washing Machine etc. [4]. Postconsumer components of above mentioned appliances have traditionally been disposed off either in domestic refuse, which ends up in landfill, were collected in designated collection spots for reuse or recycling. Iron and Steel are the most common materials found in electrical and electronic equipments and amounts to nearly half of the total weight of WEEE. Plastic are the second largest component by weight representing nearly 21 percent of WEEE [4, 5]. Plastic waste might be utilized as a partial or total replacement of fine aggregates, coarse aggregates or could be added as filler materials [6]. Since many research works were carried out using E-Waste as a partial replacement of coarse aggregate $[7,8]$. The major objective of this study is to reduce as far as possible the used and discarded electronic and electrical equipments and convert waste into socially and industrially beneficial. It is used as raw material with low cost and environmental friendly technology.

\section{Geopolymer Concrete}

Davidovits, [9] proposed that an alkaline liquid could be used to react with the silicon $(\mathrm{Si})$ and the aluminum (Al) in a source material of geological origin or in by-product materials such as fly ash, blast furnace slag, and rice husk ash to produce binders [10]. Unlike ordinary Portland cement, Geopolymer do not form 
calcium silicate hydrates for matrix formation and strength but utilize the polycondensation of silica and alumina to attain strength. Two main constituents of Geopolymer are source materials and alkaline liquid [11]. The source material should be alumino-silicate based and rich in both silica and alumina. In Geopolymer concrete, supplementary cementing materials such as Fly ash, Silica fume, Rice husk ash, Ground Granulated Blast furnace Slag (GGBS) and Metakaolin are used as alternative binders to Portland cement [12]. In this study, Fly ash and GGBS were used as alternative binders.

Geopolymer is an excellent alternative which transform industrial waste products like GGBS and fly ash into binder for concrete [11]. Geopolymer binders are used together with aggregates to produce Geopolymer concrete. They are ideal for building and repairing infrastructures and for pre-casting units, because they have very high early strength. Their setting times can be controlled and they remain intact for very long time without any need for repair [13].Geopolymer, with properties such as abundant raw resource, little $\mathrm{CO}_{2}$ emission, less energy consumption, low production cost, high early strength and fast setting. Geopolymer concrete is inorganic polymer composites, which are prospective concrete with the potential to form a substantial element of an environmentally sustainable product by replacing the conventional concrete. The major benefit of the Geopolymer is polymer is making use of industrial products. 80 to 90 percent reduction in $\mathrm{CO}_{2}$ emission can be achieved by the replacement of ordinary Portland cement (OPC) with Geopolymer cement [14].Geopolymer indicates transformation of geomolecules through geochemical process during diagnosis and can be classified into two major groups, pure inorganic and organic containing synthetic analogues of naturally occurring macromolecule. Geopolymer as initially proposed refers mainly to pure inorganic material but could be extended to include geomaterials with organic content. It is therefore important during Geopolymerisation to consider cross link between inorganic and organic species. It has good potential for production of green concrete and construction material with lower carbon foot print. Geopolymer technology has wide variety of applications in the field of industries such as automobiles, aerospace, metallurgy, civil engineering and plastic industries. It is used for coating and adhesive new binder for fiber composites, waste encapsulation and new cement for concrete.

\subsection{Fly Ash}

\section{Materials}

Fly ash is a by-product of electricity producing plant using coal as fuel. It is obtained in the form of powder. It is a good Pozzolana the colour of fly ash is either grey or blackish grey [15]. The chemical composition is mainly composed of the oxides of silicon $\left(\mathrm{SiO}_{2}\right)$, aluminium $\left(\mathrm{Al}_{2} \mathrm{O}_{3}\right)$, iron $\left(\mathrm{Fe}_{2} \mathrm{O}_{3}\right)$, and calcium $(\mathrm{CaO})$, whereas magnesium, potassium, sodium, titanium, and sulphur are also present in a lesser amount $[16$, 17].

\subsection{Ground Granulated Blast Furnace Slag (GGBS)}

Granulated Blast furnace Slag (GGBS) is obtained by quenching molten iron slag (a by-product of iron and steel making) from a blast furnace in water or steam, to produce a glassy, granular product that is then dried and ground into a fine powder [15].

\subsection{Alkaline Activators}

The most common alkaline solution used in Geo-polymerization is a combination of sodium hydroxide $(\mathrm{NaOH})$ or potassium hydroxide $(\mathrm{KOH})$ and sodium silicate $\left(\mathrm{Na}_{2} \mathrm{SiO}_{3}\right)$ or potassium silicate $\left(\mathrm{K}_{2} \mathrm{SiO}_{3}\right)[18]$. The combination of Sodium hydroxide and Sodium silicate is used as the alkaline activator in this study. Alkaline liquids are prepared by mixing of the Sodium hydroxide and Sodium silicate solutions at the room temperature at least 24 hours prior to use. [7, 19,20].

\subsection{Super plasticizer}

Conplast SP430 is a chloride free, superplasticising admixture based on selected sulphonated naphthalene polymers [18]. In this study dosage of $1.5 \%$ by mass of the cementious material was added to the mixture. It is used where a high degree of workability is required and to facilitate production of high quality concrete of improved durability and water tightness.

\subsection{E-Waste}

Rapid technology change, low initial costs have resulted in a fast growing surplus of electronic waste around the globe [7]. E- waste available in the form of loosely discarded, surplus, obsolete, broken, electrical or electronic devices from commercial recyclers have been collected which were crushed to the required particle size [15]. The E-Waste retained on IS sieve $4.75 \mathrm{~mm}$ was used in this work. The physical properties are given in TABLE 1.

\subsection{Fine Aggregate}

Fine aggregate is a naturally available granular material composed of finely divided rock and mineral particles. The locally available River sand of grade II conforming to the requirements of IS 383 is used [21]. The physical properties are given in TABLE 1 . 


\subsection{Coarse Aggregate}

Coarse aggregates are produced by disintegration of rocks and by crushing of rocks. Coarse aggregates are usually those particles which are retained on an IS $4.75 \mathrm{~mm}$ sieve. The physical properties are given in TABLE 1.

Table 1 Physical Properties of Aggregates

\begin{tabular}{|l|l|l|l|}
\hline Tests & E-Waste & Fine Aggregate & Coarse Aggregate \\
\hline Specific gravity & 2.38 & 2.67 & 2.66 \\
\hline Fineness modulus & 2.9 & 2.25 & 3.2 \\
\hline
\end{tabular}

\subsection{Mix Design}

\section{Experimental Program}

As the geopolymer concrete are new construction materials they don't have any standard mix design To identify the mix ratios for different grades of geopolymer concrete the trial and error method is followed [7] and the same is shown in TABLE 2.

Table 2 Mix Proportions

\begin{tabular}{|c|c|c|c|c|c|c|c|}
\hline \multirow[t]{2}{*}{ Mix } & \multicolumn{2}{|c|}{ Binder $\mathrm{kg} / \mathrm{m}^{3}$} & \multicolumn{2}{|l|}{$\begin{array}{l}\text { Fine Aggregate } \\
\mathrm{kg} / \mathrm{m}^{3}\end{array}$} & \multirow{2}{*}{$\begin{array}{l}\text { Coarse } \\
\text { Aggregate } \\
\text { kg/m } \mathrm{m}^{3}\end{array}$} & \multirow{2}{*}{$\begin{array}{l}\mathrm{NaOH} \\
(12 \mathrm{M}) \\
\mathrm{kg} / \mathrm{m}^{3}\end{array}$} & \multirow[t]{2}{*}{$\begin{array}{l}\mathrm{Na}_{2} \mathrm{SiO}_{3} \\
\mathrm{~kg} / \mathrm{m}^{3}\end{array}$} \\
\hline & Fly Ash & GGBS & Fine Aggregate & E-Waste & & & \\
\hline M1 & 354.8 & 39.43 & 554.4 & 0 & 1293.6 & 45.06 & 112.6 \\
\hline M2 & 354.8 & 39.43 & 498.9 & 55.44 & 1293.6 & 45.06 & 112.6 \\
\hline M3 & 354.8 & 39.43 & 443.5 & 110.88 & 1293.6 & 45.06 & 112.6 \\
\hline M4 & 354.8 & 39.43 & 388.0 & 166.32 & 1293.6 & 45.06 & 112.6 \\
\hline
\end{tabular}

To identify the optimum mix for the Geopolymer with E-Waste the various parameters and ingredients are varied. The parameters changed in the mix proportions are density, molarity and percentage ratio between the Fly ash and GGBS. Design of Geopolymer concrete mix, coarse and fine aggregates together were taken as 75 to 80 percent of entire mixture by mass [18]. The density of Geopolymer concrete is taken similar to that of $\mathrm{OPC}$ as $2400 \mathrm{~kg} / \mathrm{m}^{3}[22,23]$. The Molarity or the concentration of sodium hydroxide pellets solution is taken as $12 \mathrm{M}$. And the major parameter is the ratio between the Fly ash and GGBS which is fully replaced for ordinary cement and the percentage is varied in range of 90 and 10 percent respectively.In this study super plasticizer of about 1.5 percent and extra water of 10 percent of mass of cementious material is adopted and they are taken as extra water as $39.4 \mathrm{Kg} / \mathrm{m}^{3}$ and super plasticizer as $5.91 \mathrm{Kg} / \mathrm{m}^{3}$.Water-to-Geopolymer solids ratio by mass of 0.19 . Design compressive strength is approximately $40 \mathrm{MPa}(1: 1.405: 3.2)$.

\subsection{Mix Ratio}

According to B V Rangan procedure [22] mix ratios were arrived for this study. They are as follows.

Mix Ratio 1: $90 \%$ FLY ASH + 10\%GGBS and 100\% FA

Mix Ratio 2: 90\%FLY ASH + 10\%GGBS and 90\% FA + 10\% E-Waste

Mix Ratio 3: 90\%FLY ASH + 10\%GGBS and 80\% FA + 20\% E-Waste

Mix Ratio 4: $90 \%$ FLY ASH + 10\%GGBS and 70\% FA + 30\% E-Waste

\subsection{Compressive Strength Test}

\section{Results And Discussion}

As per IS 516 [24], the concrete was poured in the mould and tempered properly so as not to have any voids. After 24 hours these moulds were removed and test specimens were cured at ambient temperature [25]. The top surface of these specimen should be made even and smooth. These specimens are tested as shown in Fig. 1 by compression testing machine after 7 and 28 days curing. The test results are given in TABLE 3 .

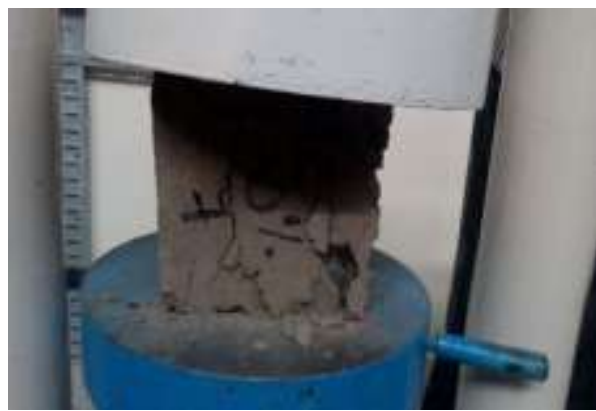

Figure1. Compressive Strength Test 
Table 3 Compressive Strength on $7^{\text {th }}$ and $28^{\text {th }}$ Day in $N / \mathrm{mm}^{2}$

\begin{tabular}{|l|l|l|l|}
\hline $\begin{array}{l}\text { Mix } \\
\text { Specification }\end{array}$ & $\begin{array}{l}\text { Percentage of } \\
\text { E-Waste }\end{array}$ & $\begin{array}{l}\mathbf{7}^{\text {th }} \mathbf{D a y} \\
\mathbf{N} / \mathbf{m m}^{\mathbf{2}}\end{array}$ & $\begin{array}{l}\mathbf{2 8}^{\text {th }} \mathbf{D a y} \\
\mathbf{N} / \mathbf{m m}^{\mathbf{2}}\end{array}$ \\
\hline Mix 1 & 0 & 23.11 & 28 \\
\hline Mix 2 & 10 & 17.55 & 19.83 \\
\hline Mix 3 & 20 & 28.2 & 32.13 \\
\hline Mix 4 & 30 & 16.59 & 22.67 \\
\hline
\end{tabular}

From the TABLE 3, for 28days, the compressive strength decreases by 30 and 19 percent for 10 and 30 percent replacement when compared with Geopolymer concrete without E-waste while compressive strength increases with 14.75 percent in 20 percentage replacement of E-Waste with fine aggregate. Compressive strength calculated as in equation 1 . The graph is plotted for the $7^{\text {th }}$ and $28^{\text {th }}$ day result of compressive strength test as shown in Fig.2.

$\mathrm{f}_{\mathrm{cy}}=$ Load at Failure/ Area of cross section

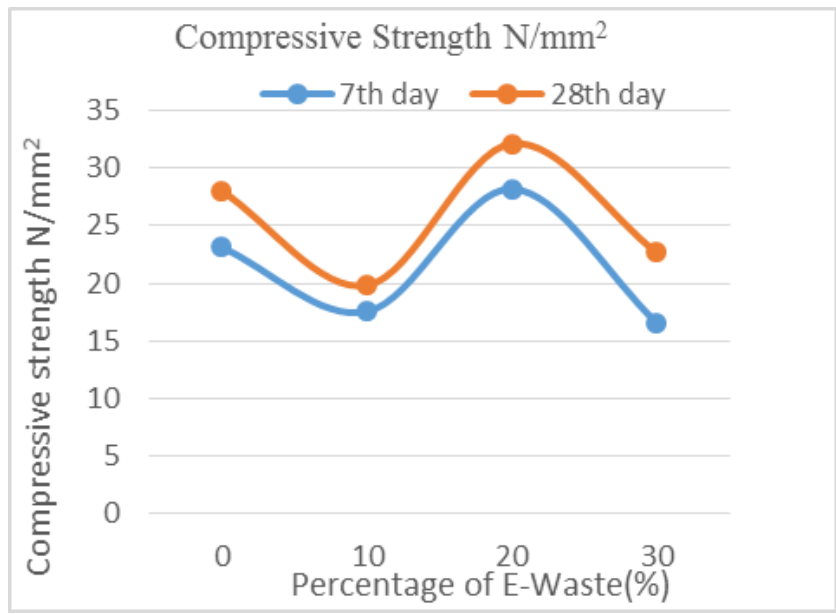

Figure 2. Chart for Compressive Strength

\subsection{Split Tensile Test}

The split tensile test is well known indirect test used for determining the tensile strength of concrete. Cylinders also referred as split tensile strength of concrete. The test consists of applying a compressive line load along the opposite generators of a concrete cylinder placed with its axis horizontally as shown in Fig.3. Due to the compression loading a fairly uniform tensile stress is developed over nearly $2 / 3$ of the loaded diameter as obtained from an elastic analysis. The magnitude of this tensile stress $f_{s p}$ is given by equation 2 [26]. The test results are given in TABLE 4.

$$
f_{s p}=\frac{2 P}{\pi D L} \mathrm{~N} / \mathrm{mm}^{2}
$$

Where,

$\mathrm{P}=$ Load at Failure $(\mathrm{N})$

$\mathrm{d}=$ diameter of the specimen $(\mathrm{mm})$

$1=$ length of the specimen $(\mathrm{mm})$

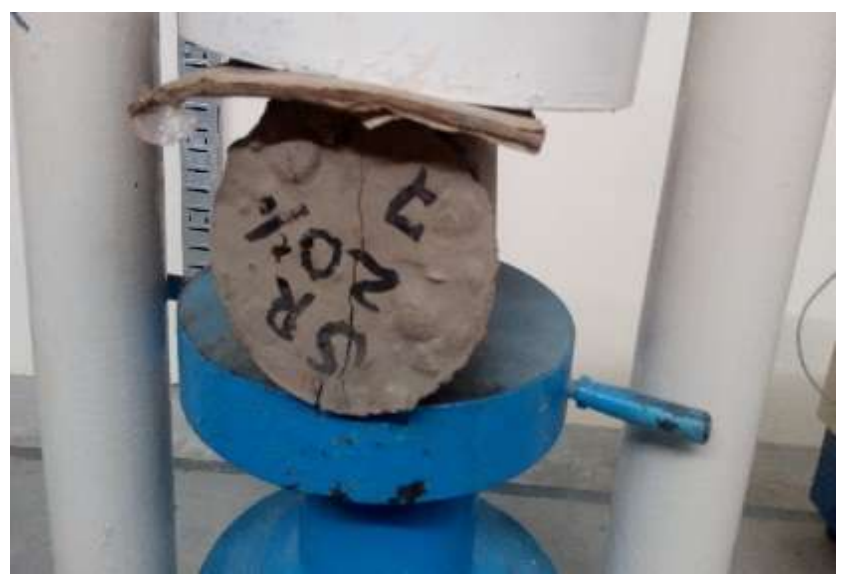

Figure 3. Split Tensile Strength Test 


\begin{tabular}{|c|c|c|c|}
\hline $\begin{array}{l}\text { Mix } \\
\text { Specification }\end{array}$ & $\begin{array}{l}\text { Percentage of } \\
\text { E-Waste }\end{array}$ & $\begin{array}{l}\text { 7th Day } \\
\text { N/mm }\end{array}$ & $\begin{array}{l}\text { 28th Day } \\
\mathrm{N} / \mathrm{mm}^{2}\end{array}$ \\
\hline Mix 1 & 0 & 2.83 & 2.92 \\
\hline Mix 2 & 10 & 1.83 & 2.21 \\
\hline Mix 3 & 20 & 3.06 & 3.11 \\
\hline Mix 4 & 30 & 1.22 & 1.69 \\
\hline
\end{tabular}

From the TABLE 4, the split tensile strength decreases by 24 and 42 percent for 10 and 30 percent replacement. The strength increases by 6.5 percent with 20 percentage replacement of E-Waste with fine aggregate. The graph is plotted for the $7^{\text {th }}$ and $28^{\text {th }}$ day of split tensile strength result as shown in Fig.4.

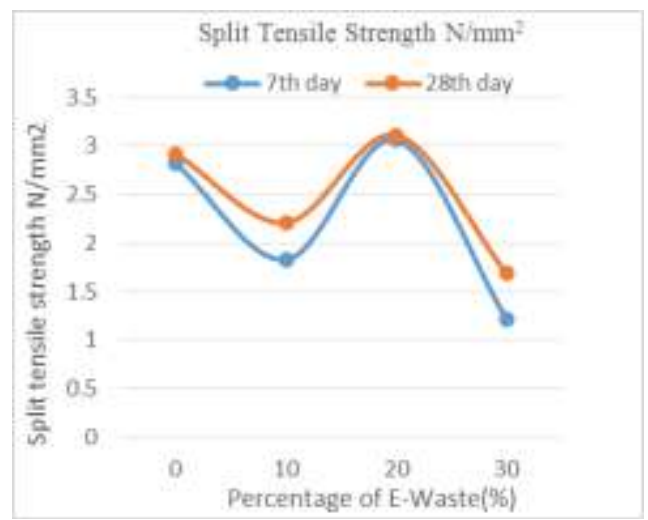

Figure 4. Chart for Split Tensile Strength

\subsection{SEM Analysis of Geopolymer Concrete with E-Waste}

After testing, samples were taken for microstructural analysis using Scanning Electron Microscopy (SEM) as shown in Fig 5 and 6. Scanning Electron Microscopy (SEM) is performed to ascertain the microstructure properties of the produced polymeric pastes of the samples. Since $20 \%$ replacement with E-waste (Mix 3) shown better result, it has been taken for SEM analysis. Fig.6a shows the least magnification at $200 \mu \mathrm{m}$ where the particle size are not uniform and Fig. $6 \mathrm{~b}$ shows the highest magnification factor at $2 \mu \mathrm{m}$ where the surface morphology is plain without cracks and well bonded for the mix 3. Geopolymer concrete with E-waste (mix3) had smooth surface without cracks and hence it can be used in concrete.

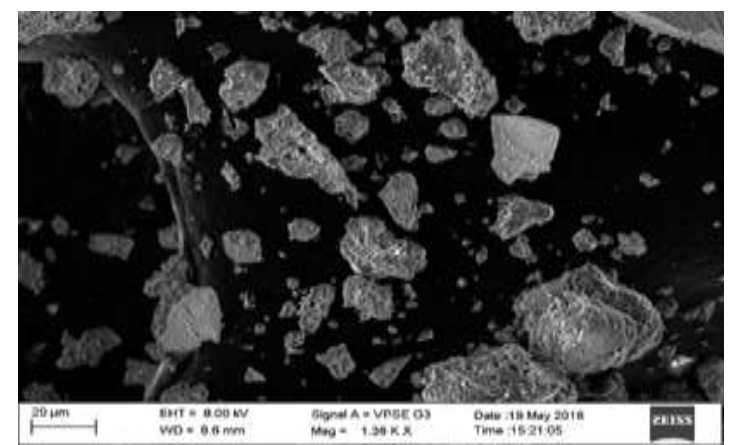

Figure 5. SEM image of Geopolymer concrete with E-Waste at $20 \mu \mathrm{m}$

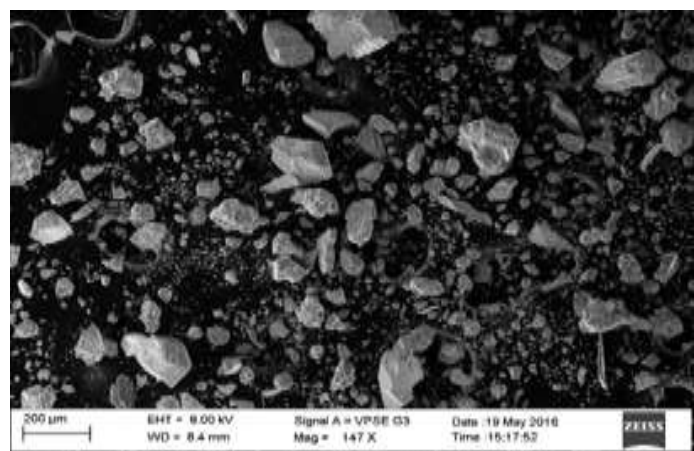

Figure 6a 


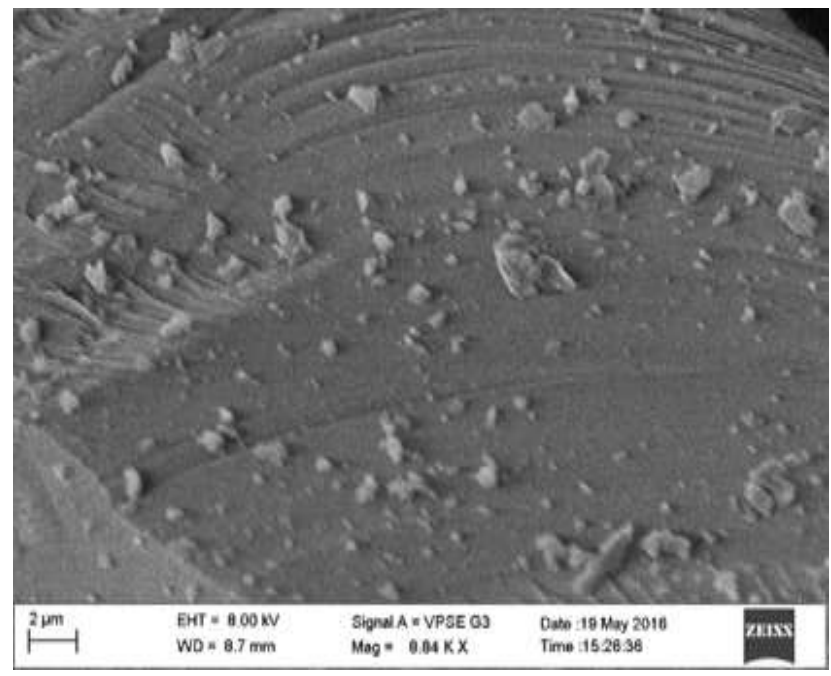

Figure 6b

Figure 6.SEM Images of geopolymer concrete with E-waste

\section{Conclusion}

The Geopolymer mix planned for this study with replacement of E-Waste found possible and economical. In this study the cement is fully replaced by industrial by-products fly ash and GGBS. The following observations were made from the present study.

- Geopolymer concrete with E-Waste gives high compressive and tensile strength than conventional Geopolymer concrete.

- Compressive and split tensile strength of Geopolymer concrete with E-Waste gives 14.75 and 6.5 percent increases compared to conventional Geopolymer concrete.

- Increase in E-waste as fine aggregate reduces the strength of concrete beyond 20 percent of replacement.

- SEM analysis test has been proved that Geopolymer concrete with E-waste has better surface configuration when compared with conventional Geopolymer concrete.

- Usage of E-waste in concrete will reduce the environmental pollution and helps to protect the environment in some extent.

\section{Acknowledgement}

Authors wish to express sincere thanks to management, Principal and Head of Civil Engineering of Sri Krishna College of Technology, Coimbatore for providing all the facilities for carrying out this work and for their encouragement in successful completion of this study.

\section{References}

[1] Shalika Sharma, Change in the Compressive Strength of Geopolymer Concrete with the Change in the Curing Time and Curing Temperature, International Journal of Emerging Technology and Advanced Engineering, 5(12), 2015, 96-99.

[2] Kale, H.I. Pathan, Recycling of Demolished Concrete and E-waste, International Journal of Science and Research (IJSR), 4(1), 2015, 789-792.

[3] Gomathi Nagajothi, Dr. T. Felixkala, Compressive Strength of Concrete Incorporated with E-fiber Waste, International Journal of Emerging Technology and Advanced Engineering, 4(4), 2014, 23-27.

[4] Krishna Prasanna, M.Kanta Rao, Strength Variations in Concrete by using E-Waste as Coarse Aggregate, International Journal of Education and Applied Research, 4(2), 2014, 82-84.

[5] Vivek S. Damal, Saurabh S. Londhe, Ajinkya B. Mane, Utilization of Electronic Waste Plastic in Concrete, International Journal of Engineering Research and Application, 5(4), 2015, 35-38.

[6] Shemal V. Dave, Ankur C. Bhogayata, Dr. N.K.Arora, Utilization of plastic waste in Geopolymer concrete: State of the art review, International Journal of Advance Engineering and Research Development, 2(12), 2015, 6-10.

[7] Prasad M. Rewane, Dr.Ushadevi S. Patil, Geopolymer with E-waste: A Greener Alternative, International Journal of Innovative Research in Technology, 2 (1), 2015, 171-178.

[8] Rajiv Gupta, Application of Recycled Coarse Aggregates and E-Waste for Pavements with Low Traffic, IOSR Journal of Mechanical and Civil Engineering, 12(2), 2015, 64-70.

[9] IS: 2386 (Part 3)-1963, Methods of testing for aggregates for concrete. Specific Gravity, Density, Absorption and Organic Impurities, Bureau of Indian Standards, New Delhi, 1963.

[10] Vijaya Rangan, Geopolymer concrete for environmental protection, The Indian Concrete Journal, 88 (4), 2014, 41-59.

[11] Maneeshkumar C.S, Manimaran G, Prasanth, An Experimental Investigation on GGBS and Fly ash Based Geopolymer Concrete with Replacement of Sand by Quarry Dust, International Journal of Engineering Research and Applications, 5(5), 2015, 91-95.

[12] Sahana, Setting Time, Compressive Strength and Microstructure of Geopolymer Paste, International Journal of Innovative Research in Science, Engineering and Technology, 2(1), 2013, 311-316. 
[13] Raijiwala D.B., Patil H.S., Geopolymer Concrete: A Concrete of Next Decade, Journal of Engineering Research and Studies, II (I), $2011,19-25$

[14] Usha, Deepa G. Nair, Subha Vishnudas, Geopolymer Binder from Industrial Wastes: Review, International Journal of Civil Engineering and Technology, 5(12), 2014, 219-225.

[15] Lakshmi.R and Nagan S., Studies on Concrete containing E plastic waste, International Journal of Environmental Sciences, 1(3), 2010, 270-281.

[16] Ammar Motorwala, Vineet Shah, Ravishankar Kamula, Praveena Nannapaneni, Prof.D.B. Raijiwala, ALKALI Activated FLY-ASH based Geopolymer Concrete, International Journal of Emerging Technology and Advanced Engineering, 3(1), 2013, $159-166$.

[17] IS: 3812-1981, Specification for fly ash for use as Pozzolana and admixture, Bureau of Indian Standards, New Delhi, 1981.

[18] Shankar H. Sanni, R. B. Khadiranaikar, Performance of Alkaline Solutions on Grades of Geopolymer Concrete, International Journal of Research in Engineering and Technology. Conference issue, 2013, 366-371.

[19] Kalaivani, Experimental Investigation for Flexural Strength of Fly Ash Concrete with Addition of Alkaline Activator, ARPN Journal of Engineering and Applied Sciences, 10(11), 2015, 4838-4831.

[20] Prakash R. Vora, Urmil V. Dave, Parametric Studies on Compressive Strength Geopolymer Concrete, Procedia Engineering, 51, 2013, $210-219$.

[21] IS: 383-1970(reaffirmed 1997), Specification for Coarse and Fine Aggregates from Natural Source for Concrete, Bureau of Indian Standards, New Delhi, 1997.

[22] Rangan and Lloyd, Geopolymer concrete with fly ash, Proc. of Second International Conf. on Sustainable Construction Materials and Technologies, Iniversita Politechnica delle Marche, Ancona, Italy, 3, 2010, 1493-1504.

[23] Khadiranaikar B., Shankar H. Sanni, Performance of Geopolymer concrete under severe environmental conditions, International Journal of Civil and Structural engineering, 3(2), 2012, 396-407.

[24] IS 516-1959, Method of Tests for Strength of Concrete, Bureau of Indian Standards, New Delhi.

[25] Rohit Zende, Mamatha.A, Study on Fly Ash and GGBS based Geopolymer Concrete under Ambient Curing, Journal of Emerging Technologies and Innovative Research (JETIR), 2(7), 2015, 3082-3087.

[26] IS 5816-1970, Method of Splitting Tensile Strength, Bureau of Indian Standards, New Delhi, 1970. 